\title{
DIAGRAM KONTROL MULTIVARIAT $n p$ \\ DAN DIAGRAM KONTROL JARAK CHI-SQUARE \\ DALAM PENGENDALIAN KUALITAS PRODUK KAIN DENIM \\ (Studi Kasus di PT Apac Inti Corpora)
}

\author{
Dwi Harti Pujiana $^{1}$, Mustafid ${ }^{2}$, Di Asih I Maruddani ${ }^{3}$ \\ 1,2,3 Departemen Statistika, Fakultas Sains dan Matematika, Universitas Diponegoro \\ e-mail :mustafid55@gmail.com
}

\begin{abstract}
Denim fabric sort number 78032 is one type of fabric in the last 4 years almost every month produced by PT Apac Inti Corpora. In the continuity of denimfabric production process, there are data defects (non-conformity) that causes the quality of denimfabric decreases. To maintain the consistency of the quality of products produced in accordance with the specified specifications, it is necessary to control the quality of the production process that has been running for this. Multiv ariate control charts attributes used are multiv ariate control charts np using the number of samples and the proportion of dis ability data with correlation between variables while the chi-square dis tance control charts use squared distances with uncorrelated data between variables. The results s howed that in the multiv ariate controlchart npthere were 2 out-of-control observations in the phase II data u sing control limits from phase I data already controlled by the value of BKA of 636321.4. While in the chi-square distance control chart showed all observations are in in-control condition with BKA value of 0.06536 . Controlled production process obtained multivariate process capability value $\left(M C_{p m}\right)$ for multivariate control np diagram of $0.625142<1$ which means the process is not capable, while the value of process capability in the chi-square distance control chart is $1.1329>1$ which means the process is capable.
\end{abstract}

Keywords: denim fabric, multivariate np control chart, chi-square distance control chart, multivariate process capability

\section{PENDAHULUAN}

Kualitas suatu produk menjadi salah satu faktor utama konsumen dalam mengkonsumsi suatu produk atau jasa. Kain denim sort number 78032 merupakan produk unggulan di PT Apac Inti Corpora. 3 variabel kecacatan yang menyebabkan kualitas kain denim berkurang, diantaranya adalah cacat loom, preparation, dan spinning sebanyak 39 pengamatan. Kain denim sort number 78032 karena merupakan salah satu jenis kain denim yang paling sering diproduksi berdasar permintaan pasar pada tahun 2014 hingga pertengahan tahun 2017 dan merupakan produk unggulan perusahaan.

Pengendalian kualitas yang dilakukan menggunakan diagram kontrol multivariat atribut, yaitu diagram kontrol multivariat $n p$ menggunakan jumlah sampel dan proporsi data kecacatan dengan korelasi antar variabel dan diagram kontrol jarak chi-square yang menggunakan jarak dikuadratkan dengan data tidak berkorelasi antar variabel. Selanjutnya untuk mengetahui kemampuan proses dari proses produksi kain denim sort number 78032 menggunakan indeks kapabilitas proses multivariat terhadap diagram kontrol multivariat $n p$ dan diagram kontrol jarak chi-square. Perhitungan kapabilitas proses multivariat dapat dihitung apabila hasil pengontrolan proses dengan diagram kontrol sudah terkontrol dan data berdistribusi normal multivariat sudah terpenuhi.

\section{TINJAUANPUSTAKA}

\subsection{Pengendalian Kualitas}

Pengendalian kualitas dilakukan agar dapat dapat memperbaiki kualitas barang atau jasa, sistem kualitas yang selalu mengalami perbaikan kontinu sehingga dapat memenuhi 
keinginan konsumen yang dapat berubah sewaktu-waktu, meningkatkan produktivitas dan kemampuan karyawan serta dapat mengurangi volume cacat dan pengerjaan ulang.

\subsection{Data Atribut}

Data atribut adalah data kualitatif yang dapat dihitung untuk pencacatan dan analisis. Data atribut bersifat diskrit, yaitu nilainya selalu berbentuk bilangan bulat. Salah satu contoh data atribut adalah jumlah cacat pada suatu produksi. Data produksi kain denim sort number 78032 termasuk dalam kategori data atribut karena didapat dari perhitungan jumlah cacat masing-masing variabel kecacatan pada produksi kain denim sort number 78032 secara keseluruhan yakni variabel loom, preparation, dan spinning.

\subsection{Diagram Kontrol Multivariat Atribut}

Menurut Mukhopadhyay (2008), jika pemeriksaan objek secara atribut dilakukan pada lebih dari satu variabel, diagram kontrol yang digunakan adalah diagram kontrol multivariat atribut. Data kecacatan kain denim terdiri dari 3 variabel, sehingga diagram kontrol yang digunakan adalah diagram kontrol multivariat.

\subsection{Dis tribusi Normal Multivariat}

Data kecacatan kain denim merupakan data diskrit, sedangkan pada pengujian normalitas menggunakan Kolmogorov-Smirnov membutuhkan data kontinu, sehingga data yang digunakan pada pengujian normalitas adalah proporsi dari data kecacatan kain denim. Langkah-langkah untuk pemeriksaan normalitas dengan uji Kolmogorov-Smirnov menurut Johnson dan Wichern (2007) adalah:

1. Menentukan nilai vektor mean proporsi dari setiap variabel $\left(\overline{\boldsymbol{p}}_{\boldsymbol{j}}\right)$

2. Menentukan nilai dari matriks varian-kovarian $S$

3. Menghitung jarak chi-square dari setiap pengamatan $\left(d_{i}^{2}\right)$ dengan rumus

$$
d_{i}^{2}=\left(\boldsymbol{p}_{i j}-\overline{\boldsymbol{p}}\right) \boldsymbol{S}^{-\mathbf{1}}\left(\boldsymbol{p}_{\boldsymbol{i j}}-\overline{\boldsymbol{p}}\right)^{T}
$$

dengan $\boldsymbol{p}_{\boldsymbol{i} \boldsymbol{j}}$ adalah vektor proporsi dari pengamatan ke- $i$ yakni

$$
\boldsymbol{p}_{\boldsymbol{i j}}=\left[\begin{array}{llll}
p_{i 1} & p_{i 2} & \ldots & p_{i k}
\end{array}\right]
$$

4. Mengurutkan nilai $d_{i}^{2}$ dari yang terkecil hingga nilai terbesar

$$
d_{(1)}^{2} \leq d_{(2)}^{2} \leq d_{(3)}^{2} \leq \ldots . \leq d_{(m)}^{2}
$$

5. Menentukan nilai $p_{i}=\frac{i-0.5}{m}$

6. Menentukan nilai $q_{i}$, dengan $q_{i, k}\left(p_{i}\right)=\chi_{k}^{2}((i-0.5) / m)$, yang diperoleh dari tabel chi-square.

7. Membuat plot $d_{(i)}^{2}$ dengan $q_{i}$ dengan titik koordinat $\left(d_{(i)}^{2}, q_{i}\right)$

Jika plot $\left(d_{(i)}^{2}, q_{i}\right)$ ini cenderung membentuk garis lurus pada gradien 1 sebesar $45^{\circ}$ nilai $d_{j}^{2} \leq \chi_{p}^{2}(0,50)$, maka $\mathrm{H}_{0}$ diterima artinya data proporsi kecacatan kain denim berdistribusi normal multivariat. Pemeriksaan normalitas menggunakan KolmogorovSmirnov dengan hipotesis sebagai berikut:

$\mathrm{H}_{0}: F\left(d_{i}^{2}\right)=F_{0}\left(d_{i}^{2}\right)$ untuk semua nilai $d_{i}^{2}$ (distribusi empiris sama dengan distribusi teoritis)

$\mathrm{H}_{1}: F\left(d_{i}^{2}\right) \neq F_{0}\left(d_{i}^{2}\right)$ paling ada satu $d_{i}^{2}$ (distribusi empiris tidak sama dengan distribusi teoritis)

dalam kasus ini distribusi teoritisnya adalah distribusi chi-square. 
$\underline{\text { Statistik uij }}$

$$
D=\sup \left|F\left(d_{i}^{2}\right)-F_{0}\left(d_{i}^{2}\right)\right|
$$

dengan $\mathrm{F}\left(d_{\mathrm{i}}{ }^{2}\right)=$ proporsi jarak mahalanobis yang kurang dari atau sama dengan $d_{\mathrm{i}}^{2}$ dan

$F_{0}\left(d_{\mathrm{i}}^{2}\right)$ adalah fungsi peluang kumulatif dari distribusi chi-square.

Kriteria Penolakan

$H_{0}$ ditolak jika $D>W_{(1-\alpha)}$, dengan $W_{(1-\alpha)}$ adalah nilai dari Tabel Kolmogorov Smirnov dengan kuantil $1-\alpha$.

\subsection{Uji Korelasi Antar Variabe I}

Uji korelasi adalah untuk menentukan seberapa erat hubungan antara dua variabel.

Pengujian koefisien korelasi sebagai berikut:

$\mathrm{H}_{0}: \rho=0$ (tidak ada hubungan antar 2 variabel)

$\mathrm{H}_{1}: \rho \neq 0$ (ada hubungan antar 2 variabel)

Statistik Uji

$$
t_{0}=\frac{r \sqrt{m-2}}{\sqrt{1-r^{2}}} \quad \text { dimana } \quad r=\frac{\sum_{i=1}^{m}\left(x_{1 i}-\bar{x}_{1}\right)\left(x_{2 i}-\bar{x}_{2}\right)}{\sqrt{\sum_{i=1}^{m}\left(x_{1 i}-\bar{x}_{1}\right)^{2}} \sqrt{\sum_{i=1}^{m}\left(x_{2 i}-\bar{x}_{2}\right)^{2}}}
$$

dimana $\mathrm{r}$ adalah koefisien korelasi dan $m$ adalah banyaknya pengamatan.

Kriteria Penolakan

$\mathrm{H}_{0}$ ditolak jika $t_{0}>t_{\alpha, m-2}$ atau nilai Sig. $<\alpha$.

\subsection{Diagram Kontrol Multivariat $n p$}

Diagram kontrol multivariat merupakan pengembangan dari diagram kontrol $n p$ untuk atribut univariat, dimana $n$ menyatakan jumlah sampel dan $p$ adalah proporsi dari kecacatan (Lu dkk, 1998). Diagram kontrol multivariat $n p$ didefinisikan melalui nilai statistik $X$ sebagai berikut:

$$
X_{i}=\sum_{j=1}^{k} \frac{C_{i j}}{\sqrt{\bar{p}_{j}}}
$$

dimana $C_{i j}$ merupakan banyaknya cacat pada pengamatan ke-i variabel ke-j dan $\bar{p}_{j}$ merupakan mean proporsi cacat pada variabel ke-j.

Ketika vektor mean proporsi cacat $\boldsymbol{p}$ belum diketahui dan matriks korelasi $\boldsymbol{\rho}$ tidak diketahui, maka diestimasi seperti di bawah ini dengan $m$ adalah banyaknya pengamatan. Vektor proporsi cacat dari sampel $i$ dan vektor mean proporsi cacat $\overline{\boldsymbol{p}}$ diestimasi sebagai berikut:

$$
\begin{aligned}
\hat{\boldsymbol{p}} & =\left[\begin{array}{cccc}
\frac{C_{11}}{n} & \frac{C_{12}}{n} & \ldots & \frac{C_{1 k}}{n} \\
\vdots & \vdots & \ddots & \vdots \\
\frac{C_{m 1}}{n} & \frac{C_{m 2}}{n} & \ldots & \frac{C_{m k}}{n}
\end{array}\right] \\
\widehat{\hat{\boldsymbol{p}}} & =\left[\begin{array}{llll}
\frac{\sum_{i=1}^{m} \hat{p}_{i 1}}{m} & \frac{\sum_{i=1}^{m} \hat{p}_{i 2}}{m} & \ldots & \frac{\sum_{i=1}^{m} \hat{p}_{i j}}{m}
\end{array}\right]=\left[\begin{array}{llll}
\hat{\bar{p}}_{1} & \hat{\bar{p}}_{2} & \ldots & \hat{\bar{p}}_{j}
\end{array}\right]
\end{aligned}
$$

Sedangkan untuk estimasi dari matriks koefiesien korelasi $\boldsymbol{\rho}$ adalah:

$$
\widehat{\boldsymbol{\rho}} \quad=\left(\rho_{j h}\right)_{k x k}
$$

diketahui bahwa $\rho_{j h}$ diperoleh dari

$$
\rho_{j h}=\frac{\operatorname{Cov}\left(C_{j}, C_{h}\right)}{\sqrt{\operatorname{Var}\left(C_{j}\right)} \sqrt{\operatorname{Var}\left(C_{h}\right)}}
$$




$$
=\frac{\sum_{i=1}^{m}\left[C_{i j}-\frac{\sum_{i=1}^{m} c_{i j}}{m}\right]\left[C_{i h}-\frac{\sum_{i=1}^{m} C_{i h}}{m}\right]}{\sqrt{\left[\sum_{i=1}^{m}\left(C_{i j}-\frac{\sum_{i=1}^{m} C_{i j}}{m}\right)^{2}\right]\left[\sum_{i=1}^{m}\left(C_{i h}-\frac{\sum_{i=1}^{m} C_{i h}}{m}\right)^{2}\right]}}
$$

dimana $j$ dan $h$ adalah variabel pada pengamatan ke- $i$ dan $k$ adalah banyaknya variabel.

Setelah diperoleh nilai-nilai estimasi vektor mean proporsi cacat $\widehat{\overline{\boldsymbol{p}}}_{\boldsymbol{j}}$ dan estimasi matriks koefisien korelasi $\widehat{\boldsymbol{\rho}}$, maka dapat diperoleh nilai-nilai statistik $X$. Diasumsikan bahwa $C_{i j}$ berdistribusi binomial karena $C_{i j}$ merupakan cacat pada pengamatan $i$ variabel $j$ dan nilai statistik $X$ dalam diagram kontrol multivariat $n p$ diasumsikan berdistribusi normal, maka estimasi mean dan varian dari statistik $X$ diperoleh sebagai berikut (Lu dkk, 1998).

$$
\begin{aligned}
& E\left(X_{i}\right)=E\left(\sum_{j=1}^{k} \frac{C_{i j}}{\sqrt{\hat{\bar{p}}_{j}}}\right)=\sum_{j=1}^{k} \frac{E\left(c_{i j}\right)}{\sqrt{\hat{\bar{p}}_{j}}}=\sum_{j=1}^{k} \frac{n \hat{p}_{j}}{\sqrt{\hat{\bar{p}}_{j}}}=n \sum_{j=1}^{k} \frac{\hat{p}_{j}}{\sqrt{\hat{\bar{p}}_{j}}}=n \sum_{j=1}^{k} \sqrt{\hat{\bar{p}}_{j}} \\
& \operatorname{Var}\left(X_{i}\right) \quad=\operatorname{Var}\left(\sum_{j=1}^{k} \frac{C_{i j}}{\sqrt{\hat{\bar{p}}_{j}}}\right) \\
& =\sum_{j=1}^{k} \frac{\operatorname{Var}\left(C_{i j}\right)}{\hat{\bar{p}}_{j}}+2 \sum_{j<h} \frac{\operatorname{Cov}\left(C_{j}, C_{h}\right)}{\sqrt{\operatorname{Var}\left(C_{j}\right)} \sqrt{\operatorname{Var}\left(C_{h}\right)}} \frac{\sqrt{\operatorname{Var}\left(C_{j}\right) \operatorname{Var}\left(C_{h}\right)}}{\sqrt{\hat{\overline{p_{j}}} \hat{\overline{p_{h}}}}} \\
& =\sum_{j=1}^{k} \frac{n \hat{\bar{p}}_{j}\left(1-\hat{\bar{p}}_{j}\right)}{\left(\sqrt{\hat{\bar{p}}_{j}}\right)^{2}}+2 \sum_{j<h} \rho_{j h} \frac{\sqrt{\hat{\bar{p}}_{j}\left(1-\hat{\bar{p}}_{j}\right) \hat{\bar{p}}_{h}\left(1-\hat{\bar{p}}_{h}\right)}}{\sqrt{\hat{\bar{p}}_{j} \hat{\bar{p}}_{h}}} \\
& =n\left\{\sum_{j=1}^{k}\left(1-\hat{\bar{p}}_{j}\right)+2 \sum_{j<h} \rho_{j h} \sqrt{\left(1-\hat{\bar{p}}_{j}\right)\left(1-\hat{\bar{p}}_{h}\right)}\right\}
\end{aligned}
$$

dimana $C_{i j}$ merupakan cacat tiap pengamatan ke- $i$ variabel ke-j dan $\hat{\bar{p}}_{j}$ merupakan mean proporsi cacat pada variabel ke-j dengan $n$ adalah jumlah keseluruhan ukuran sampel pengamatan $i$ dan $\rho_{j h}$ adalah matriks korelasi pengamatan $i$ variabel $j$.

Batas kendali yang digunakan

$$
\begin{array}{ll}
\mathrm{BKA} & =n \sum_{\mathrm{j}=1}^{\mathrm{k}} \sqrt{\hat{\bar{p}}_{j}}+3 \sqrt{n\left\{\sum_{j=1}^{k}\left(1-\hat{\bar{p}}_{j}\right)+2 \sum_{j<h} \rho_{j h} \sqrt{\left(1-\hat{\bar{p}}_{j}\right)\left(1-\hat{\bar{p}}_{h}\right)}\right\}} \\
\mathrm{GT} & =n \sum_{\mathrm{j}=1}^{\mathrm{k}} \sqrt{\hat{\bar{p}}_{j}} \\
\mathrm{BKB} & =n \sum_{j=1}^{k} \sqrt{\hat{\bar{p}}_{j}}-3 \sqrt{n\left\{\sum_{j=1}^{k}\left(1-\hat{\bar{p}}_{j}\right)+2 \sum_{j<h} \rho_{j h} \sqrt{\left(1-\hat{\bar{p}}_{j}\right)\left(1-\hat{\bar{p}}_{h}\right)}\right\}}
\end{array}
$$

Identifikasi sinyal out-of-control didefinisikan dengan nilai Z-Score:

$$
Z_{j}=\left[C_{i j}-n \hat{\bar{p}}_{j}\right] / \sqrt{\hat{\bar{p}}_{j}}
$$

dimana $Z_{j}$ adalah skor statistik pada variabel ke-j.

Identifikasi sinyal out-of-control dilakukan jika diagram multivariat menunjukkan sinyal out-of-control daridua atau lebih variabel yang berkolerasi dan menyebabkan proses tidak terkendali. Jika terlihat sinyal out-of-control maka dihitung masing-masing skor $Z_{j}$ untuk tiap variabel. Apabila diasumsikan $Z_{1}$ dan $Z_{k}$ memberikan skor terkecil dan skor terbesar, apabila $X$ berada di atas batas kendali atas, maka $Z_{k}$ memberikan skor positif 
terbesar dan variabel $k$ diyakini sebagai kontributor terkritis pada proses kerusakan yang paling tinggi.

\subsection{Diagram Kontrol Jarak Chi-Square}

Jarak chi-square merupakan nilai jumlahan kuadrat dari setiap jarak antara proporsi cacat $p_{i j}$ dengan mean proporsi cacat $\bar{p}_{j}$ yang dibagi dengan mean proporsi cacat itu sendiri. Berdasarkan Yuswantara dan Haryono (2010), proporsi dihitung dengan rumus:

$$
p_{i j}=\frac{c_{i j}}{m_{i j}}
$$

dengan $C_{i j}$ adalah cacat pada pengamatan ke- $i$ variabel ke-j, dan $m_{i j}$ adalah banyak pengamatan yang digunakan pada pengamatan ke- $i$ variabel ke- $j$. Sedangkan untuk rata-rata proporsi adalah:

$$
\bar{p}_{j}=\frac{\sum_{i=1}^{m} p_{i j}}{m}
$$

dengan $m$ adalah banyaknya pengamatan yang dilakukan dan $p_{i j}$ adalah nilai proporsi pada pengamatan ke- $i$ dan variabel ke- $j$.

Diagram kontrol jarak chi-square dapat diterapkan pada variabel multivariat dengan antar variabel cacat tidak saling berkorelasi (Ye dkk, 2003). Diagram kontrol jarak chisquare didefinisikan:

$$
\chi_{i}^{2}=\sum_{j=1}^{k} \frac{\left(p_{i j}-\bar{p}_{j}\right)^{2}}{\bar{p}_{j}} \quad, j=1,2, . ., k \quad \mathrm{i}=1,2, . ., m
$$

dimana $\chi_{\mathrm{i}}^{2}$ adalah jarak chi-square daripengamatan ke- $i$ dan $\bar{p}_{j}$ adalah mean proporsi cacat variabel ke-j.

dengan standar deviasinya adalah

$$
S_{\bar{\chi}^{2}}=\sqrt{\frac{\sum_{i=1}^{m}\left(\chi_{i}^{2}-\bar{\chi}^{2}\right)^{2}}{m-1}}
$$

Karena jarak selalu bernilai positif, maka batas kendali yang diperoleh

$$
\begin{aligned}
& \text { BKA }=\bar{\chi}^{2}+3 S_{\bar{\chi}^{2}} \\
& \text { Rata-rata }=\bar{\chi}^{2} \\
& \text { BKB }=0
\end{aligned}
$$

\subsection{Kapabilitas Proses Multivariat}

Kapabilitas proses multivariat $\left(M C_{p m}\right)$ dapat menggambarkan lokasi nilai rata-rata proses terhadap nilai target berdasarkan elips pada karakteristik mutu tersebut. Perhitungan nilai kapabilitas proses multivariat $(\mathrm{MCpm})$ didefinisikan sebagai rasio dari dua volume yaitu

$$
M C_{p m}=\frac{\operatorname{vol}\left(R_{1}\right)}{\operatorname{vol}\left(R_{2}\right)}
$$

dengan $R_{1}$ merupakan daerah spesifikasi, sedangkan $R_{2}$ merupakan daerah proses variasi. Jika data berdistribusi normal multivariat maka $R_{l}$ dan $R_{2}$ berbentuk ellipsoid, dengan $R_{l}$ dibentuk oleh batas spesifikasi pada setiap variabel. Volume $R_{1}$ adalah

$$
\operatorname{vol}\left(R_{1}\right)=\frac{2 \prod_{j=1}^{k} T_{j}}{k} \frac{\pi^{k / 2}}{\Gamma(k / 2)}
$$

dengan nilai $\pi=3.14$ dan $T_{j}$ merupakan nilai target spesifikasi ke-j $(j=1,2, \ldots k)$ yang dapat ditentukan oleh perusahaan atau dihitung seperti pada persamaan

$$
T=\frac{U S L+L S L}{2}
$$

USL merupakan batas atas spesifikasi dan LSL merupakan batas bawah spesifikasi. Volume $R_{2}$ yaitu $\operatorname{vol}\left(R_{2}\right)=\operatorname{vol}\left[\left(\boldsymbol{p}_{\boldsymbol{i} \boldsymbol{j}}-\overline{\boldsymbol{p}}_{\boldsymbol{j}}\right) \boldsymbol{S}_{T}^{-\mathbf{1}}\left(\boldsymbol{p}_{\boldsymbol{i} \boldsymbol{j}}-\overline{\boldsymbol{p}}_{\boldsymbol{j}}\right)^{\prime} \leq K(k)\right]$ 
Sehingga, kapabilitas proses multivariat dapat dituliskan sebagai berikut:

$$
M C_{p m}=\frac{\operatorname{vol}\left(R_{1}\right)}{\left(\boldsymbol{p}_{i j}-\overline{\boldsymbol{p}}_{\boldsymbol{j}}\right)^{\prime} \boldsymbol{S}_{T}^{-\mathbf{1}}\left(\boldsymbol{p}_{\boldsymbol{i j}}-\overline{\boldsymbol{p}}_{\boldsymbol{j}}\right) \leq K(k)}
$$

dengan $K(k)$ merupakan kuantil $99,73 \%$ dari distribusi $\chi^{2}$ dengan derajat bebas k dan

$$
\begin{aligned}
S_{T} & =\frac{1}{m-1} \sum_{j=1}^{k}\left(\overline{\boldsymbol{p}}_{\boldsymbol{j}}-\boldsymbol{T}_{\boldsymbol{j}}\right) \boldsymbol{S}^{-\mathbf{1}}\left(\overline{\boldsymbol{p}}_{\boldsymbol{j}}-\boldsymbol{T}_{\boldsymbol{j}}\right)^{\prime} \\
& =S+\frac{m}{m-1}\left(\overline{\boldsymbol{p}}_{\boldsymbol{j}}-\boldsymbol{T}_{\boldsymbol{j}}\right) \boldsymbol{S}^{-\mathbf{1}}\left(\overline{\boldsymbol{p}}_{\boldsymbol{j}}-\boldsymbol{T}_{\boldsymbol{j}}\right)^{\prime}
\end{aligned}
$$

Sehingga bagian penyebut dapat dituliskan dalam bentuk:

$$
\begin{aligned}
\operatorname{vol}\left(R_{2}\right) & =\operatorname{vol}\left[\left(\boldsymbol{p}_{\boldsymbol{i j}}-\overline{\boldsymbol{p}}_{\boldsymbol{j}}\right) \boldsymbol{S}_{T}^{-\mathbf{1}}\left(\boldsymbol{p}_{\boldsymbol{i} \boldsymbol{j}}-\overline{\boldsymbol{p}}_{\boldsymbol{j}}\right)^{\prime} \leq K(k)\right] \\
= & \left|S_{T}\right|^{1 / 2}(\pi K)^{k / 2}[\Gamma(k / 2+1)]^{-1} \\
= & |S|^{1 / 2}(\pi K)^{k / 2}[\Gamma(k / 2+1)]^{-1} \mathrm{X}\left[1+\frac{m}{m-1}\left(\overline{\boldsymbol{p}}_{\boldsymbol{j}}-\boldsymbol{T}_{\boldsymbol{j}}\right) \boldsymbol{S}^{-\mathbf{1}}\left(\overline{\boldsymbol{p}}_{\boldsymbol{j}}-\boldsymbol{T}_{\boldsymbol{j}}\right)^{\prime}\right]^{1 / 2}
\end{aligned}
$$

Nilai indeks kapabilitas proses multivariat $\left(M C_{p m}\right)$ ditentukan dengan rumus:

$$
M C_{p m}=\frac{\operatorname{vol}\left(R_{1}\right)}{|S|^{1 / 2}(\pi K)^{k / 2}[\Gamma(k / 2+1)]^{-1}} \times \frac{1}{\left[1+\frac{m}{m-1}\left(\overline{\boldsymbol{p}}_{j}-\boldsymbol{T}_{\boldsymbol{j}}\right) \boldsymbol{S}^{-\mathbf{1}}\left(\overline{\boldsymbol{p}}_{\boldsymbol{j}}-\boldsymbol{T}_{\boldsymbol{j}}\right)^{\prime}\right]^{1 / 2}}
$$

Pada perhitungan kapabilitas proses multivariat $\left(M C_{p m}\right)$, apabila nilai $M C_{p m}>1$ maka proses mempunyai variasi lebih kecil dibandingkan dengan batas spesifikasi sehingga dapat dikatakan proses produksi telah berjalan dengan baik. Sebaliknya, apabila nilai kapabilitas proses multivariat $\left(M C_{p m}\right)<1$ menunjukkan variasi proses lebih besar daripada batas spesifikasi perusahaan. Artinya proses tersebut banyak menghasilkan produk yang tidak sesuai dengan spesifikasi.

\section{METODOLOGI PENELITIAN}

Data yang digunakan merupakan data sekunder kecacatan pada kain denim 3 variabel penyebab kecacatan pada kain denim sort number 78032 yakni variabel loom, preparation, dan spinning periode Januari 2014 sampai Mei 2017 sejumlah 39 pengamatan di PT Apac Inti Corpora.

\section{HASIL DAN PEMBAHASAN}

\subsection{Deskriptif Data}

Statistik deskriptif untuk data kecacatan pada kain denim sort number 78032 terhadap 3 variabel yakni variabel loom diperoleh nilai mean sebesar 15150, varian sebesar 75932911, dan nilai standar deviasi sebesar 8714. Variabel preparation diperoleh nilai mean sebesar 5981, varian sebesar 9024101, dan nilai standar deviasi sebesar 3004, sedangkan variabel spinning diperoleh nilai mean sebesar 8894 , varian sebesar 27701115 , dan nilai standar deviasi sebesar 5263.

\subsection{Diagram Pare to}

Diagram pareto menunjukkan bahwa variabel dengan jumlah kecacatan terbesar adalah cacat loom dengan presentase sebesar 50.5\% atau 590836 cacat. Variabel dengan jumlah kecacatan terbesar kedua adalah spinning, dengan presentase sebesar $29.6 \%$ atau 346875 cacat. Sedangkan variabel terkecil yang menyababkan menurunnya kualitas kain denim adalah cacat preparation dengan presentase $19.9 \%$ atau 233246 cacat.

\subsection{Diagram Kontrol Multivariat $n p$}

\subsubsection{Uji Normal Multivariat}

Uji normal multivariat digunakan sebagai salah satu syarat untuk melakukan analis is menggunakan diagram kontrol multivariat dan analisis kapabilitas proses. Data yang 
digunakan merupakan data dikrit dari cacat kain denim, sehingga pada pengujian normal multivariat menggunakan data proporsi dari cacat kain denim berdasarkan rumus (5). Sehingga uji normal multivariat pada data cacat kain denim dapat dilakukan menggunakan software $R$ dan didapatkan hasil.

Hipotesis

$H_{0}: F\left(d_{i}^{2}\right)=F_{0}\left(d_{i}^{2}\right)$ untuk semua nilai $d_{i}^{2}$ (distribusi empiris sama dengan distribusi chi-square)

$H_{1}: F\left(d_{i}^{2}\right) \neq F_{0}\left(d_{i}^{2}\right)$ untuk sekurang-kurangnya sebuah nilai $d_{i}^{2}$ (distribusi empiris tidak sama dengan distribusi chi-square)

Taraf Signifikansi $\alpha=5 \%$.

Statistik uji

\section{Kriteria Penolakan}

$$
D=0.1625 \text { dan } P \text {-value }=0.2282 \text {. }
$$

Keputusan

$$
\mathrm{H}_{0} \text { ditolak jika nilai } D>W_{(1-\alpha)} \text {. }
$$

$\mathrm{H}_{0}$ diterima karena nilai $D=0.1625<W_{(1-0.05)}=0.210$.

Kesimpulan

Pada taraf signifikansi $\alpha=5 \%$, terjadi penerimaan $\mathrm{H}_{0}$ dimana $F\left(d_{i}^{2}\right)=F_{0}\left(d_{i}^{2}\right)$ untuk semua nilai $d_{i}^{2}$ atau distribusi empiris sama dengan distribusi chi-square sehingga dapat disimpulkan bahwa data proporsi cacat kain denim berdistribusi normal multivariat.

\subsubsection{Uji Korelasi Antar Variabel}

Data yang digunakan merupakan data multivariat sehingga perlu dilakukan adanya uji korelasi antar variabel. Koefisien korelasi antar variabel digunakan untuk mengetahui seberapa besar hubungan atau keterkaitan antar masing-masing variabel.

Hipotesis

$H_{0}: \rho=0$ (tidak ada hubungan antar 2 variabel)

$H_{1}: \rho \neq 0$ (ada hubungan antar 2 variabel)

Taraf Signifikansi $\alpha=5 \%$.

Statistik Uji

Nilai korelasi pearson, dan Sig. ditunjukkan pada Tabel 1.

Kriteria Penolakan

$\mathrm{H}_{0}$ ditolak jika nilai Sig. $<\alpha=5 \%$.

Keputusan dan Kesimpulan

Tabel 1. Keputusan dan Kesimpulan dari Uji Korelasi

\begin{tabular}{|c|c|c|c|c|c|}
\hline \multicolumn{2}{|c|}{ Variabel } & Korelasi Pearson & Sig. & Keputusan & Kesimpulan \\
\hline loom & Loom & 1 & - & - & - \\
\hline & preparation & 0.899 & 0.000 & $\mathrm{H}_{0}$ ditolak & Ada Hubungan \\
\hline & spinning & 0.939 & 0.000 & $\mathrm{H}_{0}$ ditolak & Ada Hubungan \\
\hline preparation & loom & 0.899 & 0.000 & $\mathrm{H}_{0}$ ditolak & Ada Hubungan \\
\hline & preparation & 1 & - & - & - \\
\hline & spinning & 0.895 & 0.000 & $\mathrm{H}_{0}$ ditolak & Ada Hubungan \\
\hline spinning & loom & 0.939 & 0.000 & $\mathrm{H}_{0}$ ditolak & Ada Hubungan \\
\hline & preparation & 0.895 & 0.000 & $\mathrm{H}_{0}$ ditolak & Ada Hubungan \\
\hline & spinning & 1 & - & - & - \\
\hline
\end{tabular}

\subsubsection{Pengontrolan Proses Fase I}


Pada pengontrolan proses produksi fase I data yang digunakan adalah data proporsi cacat kain denim sort number 78032 sebanyak 15 sampel dengan ukuran sampel $n=1900540$ pada Januari 2014 sampai Maret 2015. Langkah selanjutnya adalah mengestimasi parameter yaitu mean proporsi produk cacat tiap karakteristik cacat. Berdasarkan rumus (6) diperoleh nilai estimasi $\bar{p}_{i}$ jika diurutan dari yang terbesar ke terkecil adalah variabel loom sebesar 0.0109519 , preparation sebesar 0.004393 dan spinning sebesar 0.005915 .

Setelah diperoleh nilai koefisien korelasi dan estimasi $\bar{p}_{i}$, maka selanjutnya adalah menghitung batas kontrol untuk diagram kontrol multivariat $n p$ dan menghitung statistik $X$ berdasarkan rumus (4). Pada data fase I digunakan data sebanyak 15 sampel dengan ukuran sampel dengan $\mathrm{n}=1900540$, menggunakan rumus (11) diperoleh nilai $\mathrm{BKA}=636321.4$, $\mathrm{GT}=617444.4$ dan $\mathrm{BKB}=0$. Sehingga plot antara statistik $X$ dan batas kendali adalah:

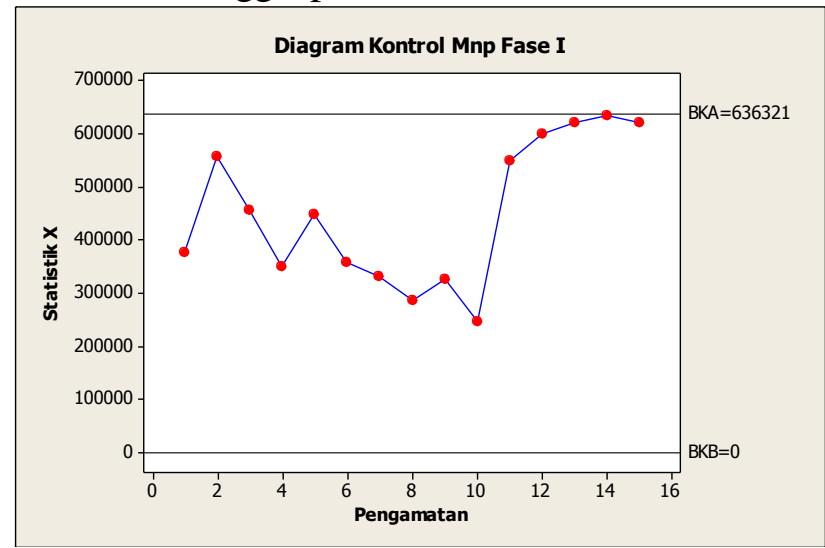

Gambar 1. Diagram Kontrol Mnp Fase I

Pada gambar 1, semua pengamatan pada data fase I sebanyak 15 sampel berada pada kondisi in-control karena tidak ada titik yang berada di luar batas kendali, sehingga dapat disimpulkan bahwa proses produksi pada fase I sudah terkendali karena semua pengamatan sudah berada dalam batas kontrol yang diperoleh. Sehingga dapat dilakukan pengujian pada data fase II menggunakan batas kendali data fase I, yakni BKA $=636321.4$, GT $=617444.4$ dan $\mathrm{BKB}=0$.

\subsubsection{Pengontrolan Proses Fase II}

Pengontrolan proses produksi fase II menggunakan data proporsi kecacatan kain denim sort number 78032 diambil sebanyak 24 sampel pada April 2015 sampai Mei 2017 dengan ukuran sampel $n=1666370$. Dengan menggunakan parameter dan batas-batas kontrol pada fase I yaitu $\mathrm{BKA}=636321.4, \mathrm{GT}=617444.4, \mathrm{BKB}=0$, dan setelah menghitung statistik $X$ berdasarkan rumus (4) untuk data fase II, maka plot antara statistik $X$ dan batas kontrolnya adalah:

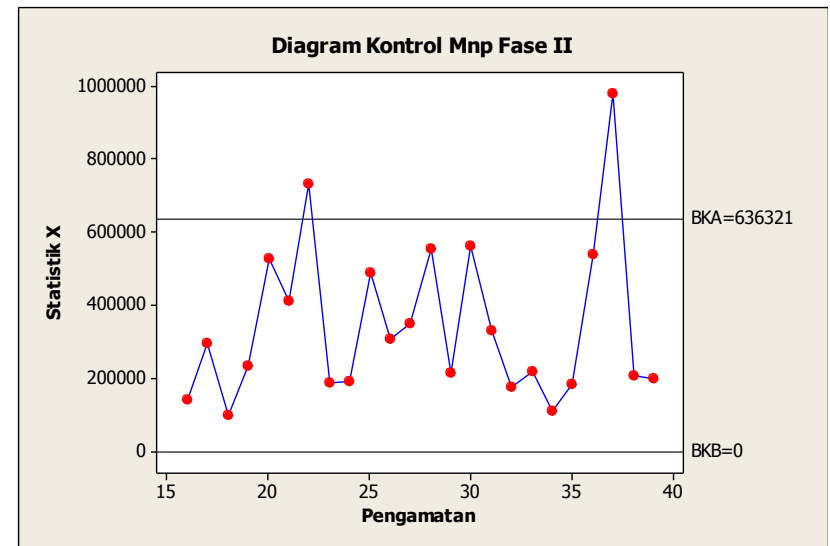

Gambar 2. Diagram Kontrol Mnp Fase II 
Dari gambar 2 terdapat beberapa 2 pengamatan yang out-of-control atau berada di luar batas kendali yaitu pengamatan ke-22 dengan nilai statistik X sebesar 732939 dan pengamatan ke-37 dengan nilai statistik X sebesar 977556. Maka proses selanjutnya adalah menelusuri variabel mana saja yang berperan paling tinggi menyebabkan sinyal out-ofcontrol.

\subsubsection{Identifikasi Sinyal Out-of-control}

Pada proses pengontrolan fase II terdapat 2 pengamatan yang keluar dari batas kendali, sehingga perlu dilakukan perbaikan proses. Oleh karena itu, diperlukannya identifikasi sinyal out-of-control yang bertujuan untuk menelusuri variabel mana saja yang menyebabkan out-of-control agar perbaikan proses dapat mencapai hasil yang maksimal.

Pada diagram kontrol multivariat $n p$, untuk mengidentifikasi sinyal out-of-control dari pengamatan dengan cara menghitung statistik $Z_{i}$ pada setiap pengamatan yang out-ofcontrol. Berdasarkan rumus (12), nilai statistik $\mathrm{Z}_{\mathrm{i}}$ untuk setiap pengamatan yang out-ofcontrol ditunjukkan pada Tabel 2.

Tabel 2. Variabel yang out-of-control

\begin{tabular}{|c|c|c|c|}
\hline \multirow{2}{*}{ Pengamatan } & \multicolumn{3}{|c|}{ Variabel } \\
\cline { 2 - 4 } & 1 & 2 & 3 \\
\hline 22 & 102221 & 79936.1 & 207569 \\
\hline 37 & 248974 & 151463 & 233905 \\
\hline
\end{tabular}

Berdasarkan tabel 2 dapat disimpulkan bahwa pengamatan ke-22 nilai $\mathrm{Z}_{\mathrm{i}}$ tertinggi adalah $\mathrm{Z}_{3}=207569$, sehingga dapat disimpulkan bahwa kontributor terbesar penyebab out-ofcontrol pengamatan ke-22 adalah variabel 3 yakni cacat karena spinning, dan pada pengamatan ke-37 nilai $Z_{\mathrm{i}}$ tertinggi adalah $\mathrm{Z}_{3}=248974$, sehingga dapat disimpulkan bahwa kontributor terbesar penyebab out-of-control pengamatan ke-37 adalah variabel 1 yakni cacat karena loom.

\subsection{Diagram Kontrol Jarak Chi-Square}

\subsubsection{Uji Normal Multivariat}

Uji normal multivariat digunakan sebagai salah satu syarat untuk melakukan analisis menggunakan diagram kontrol multivariat dan analisis kapabilitas proses. Data yang digunakan merupakan data dikrit dari cacat kain denim, sehingga pada pengujian normal multivariat menggunakan data proporsi dari cacat kain denim berdasarkan rumus (13). Sehingga uji normal multivariat pada data cacat kain denim dapat dilakukan menggunakan software $R$ dan didapatkan hasil.

Hipotesis

$H_{0}: F\left(d_{i}^{2}\right)=F_{0}\left(d_{i}^{2}\right)$ untuk semua nilai $d_{i}^{2}$ (distribusi empiris sama dengan distribusi chi-square)

$H_{1}: F\left(d_{i}^{2}\right) \neq F_{0}\left(d_{i}^{2}\right)$ untuk sekurang-kurangnya sebuah nilai $d_{i}^{2}$ (distribusi empiris tidak sama dengan distribusi chi-square)

Taraf Signifikansi $\alpha=5 \%$.

Statistik uji

$$
D=0.196 \text { dan } P \text {-value }=0.0957 \text {. }
$$

Kriteria Penolakan

Keputusan

$$
\mathrm{H}_{0} \text { ditolak jika nilai } D>W_{(1-\alpha)} \text {. }
$$

$\mathrm{H}_{0}$ diterima karena nilai $D=0.196<W_{(1-0.05)}=0.210$. 
Kesimpulan

Pada taraf signifikansi $\alpha=5 \%$, terjadi penerimaan $\mathrm{H}_{0}$ dimana $F\left(d_{i}^{2}\right)=F_{0}\left(d_{i}^{2}\right)$ untuk semua nilai $d_{i}^{2}$ atau distribusi empiris sama dengan distribusi chi-square sehingga dapat disimpulkan bahwa data proporsi cacat kain denim berdistribusi normal multivariat.

\subsubsection{Batas Kendali Diagram Kontrol Jarak Chi-Square}

Data yang digunakan adalah data proporsi kecacatan kain denim sort number 78032 sebanyak 39 pengamatan. Langkah pertama dalam perhitungan diagram kontrol jarak chisquare adalah menghitung jarak chi-square berdasarkan rumus (15). Setelah mendapatkan nilai jarak chi-square, menggunakan rumus (17), diperoleh $\mathrm{BKA}=0.06536, \mathrm{GT}=0.01288$, dan $\mathrm{BKB}=0$. Sehingga plot antara jarak chi-square dan batas kontrolnya adalah:

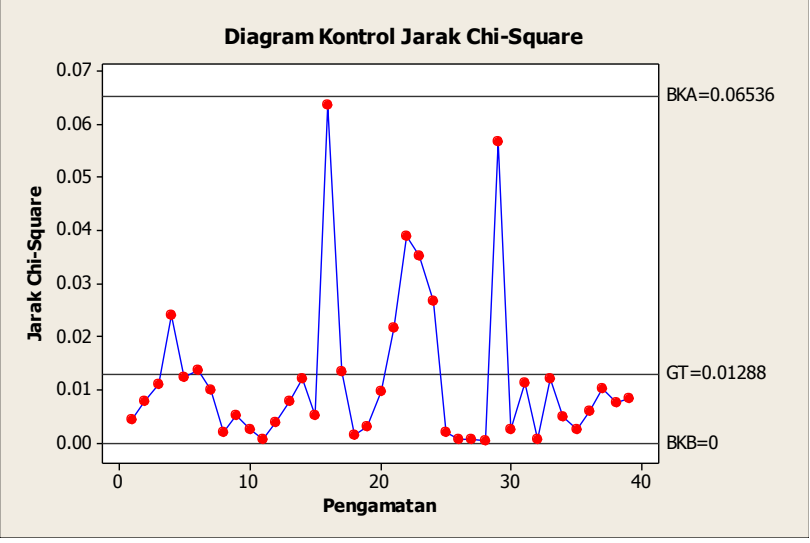

Gambar 3. Diagram Kontrol Jarak Chi-Square

Pada gambar 3 semua pengamatan berada pada kondisi in-control karena tidak ada pengamatan yang berada di luar batas kendali, sehingga dapat disimpulkan bahwa proses sudah terkendali dengan nilai $\mathrm{BKA}=0.06536$, rata-rata $=0.01288$, dan $\mathrm{BKB}=0$.

\subsection{Kapabilitas Proses Multivariat}

\subsubsection{Diagram Kontrol Multivariat $n p$}

Perhitungan nilai $M C_{p m}$ menggunakan software Microsoft Excel. Sebelum menghitung nilai $M C_{p m}$, terlebih dahulu menentukan nilai target $\left(T_{j}\right)$ per variabel berdasarkan rumus (20). Diperoleh nilai $T_{1}=114927.8, T_{2}=82786.99$, dan $T_{3}=$ 125145. Selanjutnya, menghitung daerah batas spesifikasi (volume $R_{l}$ ) yaitu daerah elipsoida yang menyatakaan target spesifikasi dari masing-masing variabel karakteristik. Nilai $T_{j}$ yang diperoleh pada persamaan (20) kemudian disubstitusikan ke bentuk persamaan (21).

$$
\operatorname{vol}\left(R_{1}\right)=\frac{2 \prod_{j=1}^{k} T_{j}}{k} \frac{\pi^{k / 2}}{\Gamma(k / 2)}=\frac{2(114927.8 \mathrm{x} \ldots \mathrm{x} 125145)}{3} \times \frac{\pi^{3 / 2}}{\Gamma(3 / 2)}=4.98504 \mathrm{E}+15
$$

Kemudian menghitung daerah proses variasi (volume $R_{2}$ ) yang juga berbentuk elipsoida, diketahui nilai $\Gamma(5 / 2)=1.3290033$ dan $\mathrm{K}(3)=14.15625$.

$$
\begin{aligned}
\operatorname{vol}\left(R_{2}\right) & =\operatorname{vol}\left[\left(\boldsymbol{p}_{\boldsymbol{i} \boldsymbol{j}}-\overline{\boldsymbol{p}}_{\boldsymbol{j}}\right) \boldsymbol{S}_{T}^{-\mathbf{1}}\left(\boldsymbol{p}_{\boldsymbol{i} \boldsymbol{j}}-\overline{\boldsymbol{p}}_{\boldsymbol{j}}\right)^{\prime} \leq K(k)\right] \\
& =\operatorname{det}\left[\begin{array}{ccc}
1947366339.92 & \ldots & 1277148585.81 \\
1074605951.52 & \ldots & 827981585.64 \\
1277148585.81 & \ldots & 1784263512.80
\end{array}\right]^{\frac{1}{2}} \mathrm{x}(3.14 \times \mathrm{K}(3))^{2} \mathrm{x}[\Gamma(5 / 2)]
\end{aligned}
$$




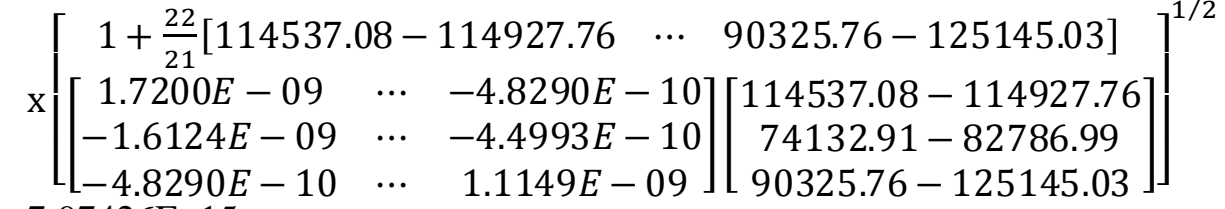

$$
\begin{aligned}
& =7.97426 \mathrm{E}+15
\end{aligned}
$$

Berdasarkan persamaan (21) dan (24) diperoleh nilai kapabilitas proses multivariat $\left(M C_{p m}\right)$.

$$
\begin{aligned}
& M C_{p m}=\frac{\operatorname{vol}\left(R_{1}\right)}{|S|^{1 / 2}(\pi K)^{k / 2}[\Gamma(k / 2+1)]^{-1}} \times \frac{1}{\left[1+\frac{m}{m-1}\left(\overline{\boldsymbol{p}}_{\boldsymbol{j}}-\boldsymbol{T}_{\boldsymbol{j}}\right) \boldsymbol{S}^{-\mathbf{1}}\left(\overline{\boldsymbol{p}}_{\boldsymbol{j}}-\boldsymbol{T}_{\boldsymbol{j}}\right)^{\prime}\right]^{1 / 2}} \\
& M C_{p m}=\frac{\operatorname{vol}\left(R_{1}\right)}{\operatorname{vol}\left(R_{2}\right)}=\frac{4.98504 \mathrm{E}+15}{7.97426 \mathrm{E}+15}=0.625142
\end{aligned}
$$

Pada perhitungan kapabilitas proses multivariat $\left(M C_{p m}\right)$ menghasilkan nilai $0.625142<1$, sehingga proses multivariat dari variabel loom, preparation, dan spinning tidak capable.

\subsubsection{Diagram Kontrol Jarak Chi-Square}

Sebelum menghitung nilai $M C_{p m}$, terlebih dahulu menentukan nilai target $\left(T_{j}\right)$ per variabel berdasarkan rumus (20) diperoleh nilai $T_{1}=0.167535, T_{2}=0.070545$, dan $T_{3}=$ 0.10506. Selanjutnya, menghitung daerah batas spesifikasi (volume $R_{1}$ ) yaitu daerah elipsoida yang menyatakaan target spesifikasi dari masing-masing variabel karakteristik. Nilai $T_{j}$ yang diperoleh pada persamaan (20) kemudian disubstitusikan ke bentuk persamaan (21).

$$
\operatorname{vol}\left(R_{1}\right)=\frac{2 \prod_{j=1}^{k} T_{j}}{k} \frac{\pi^{k / 2}}{\Gamma(k / 2)}=\frac{2(0.167535 \times \ldots \times 0.10506)}{3} \times \frac{\pi^{3 / 2}}{\Gamma(3 / 2)}=0.0052
$$

Kemudian menghitung daerah proses variasi (volume $R_{2}$ ) yang juga berbentuk elipsoida, diketahui nilai $\Gamma(5 / 2)=1.3290033$ dan $\mathrm{K}(3)=14.15625$.

$$
\begin{aligned}
\operatorname{vol}\left(R_{2}\right)= & \operatorname{vol}\left[\left(\boldsymbol{p}_{\boldsymbol{i} \boldsymbol{j}}-\overline{\boldsymbol{p}}_{\boldsymbol{j}}\right) \boldsymbol{S}_{T}^{-\mathbf{1}}\left(\boldsymbol{p}_{\boldsymbol{i} \boldsymbol{j}}-\overline{\boldsymbol{p}}_{\boldsymbol{j}}\right)^{\prime} \leq K(k)\right] \\
= & \operatorname{det}\left[\begin{array}{lll}
0.0004169 & \ldots & 0.0000537 \\
0.0000519 & \ldots & 0.0000239 \\
0.0000537 & \ldots & 0.0003425
\end{array}\right]^{\frac{1}{2}} \times(3.14 \times \mathrm{K}(3))^{2} \times[\Gamma(5 / 2)] \\
& \times\left[\begin{array}{ccc}
\left.1+\frac{39}{38}\left[\begin{array}{lll}
0.1667-0.1675 & 0.0659-0.0705 & 0.0959-0.1050
\end{array}\right]\right]^{1 / 2} \\
=0.00459
\end{array}\left[\begin{array}{ccc}
2650.3264 & -1715.6444 & -296.0736 \\
-1715.6444 & 14547.0355 & -744.4831 \\
-296.0736 & -744.4831 & 3018.0081
\end{array}\right]\left[\begin{array}{c}
0.1667-0.1675 \\
0.0659-0.0705 \\
0.0959-0.1050
\end{array}\right]\right]^{-1}
\end{aligned}
$$

Berdasarkan persamaan (21) dan (24) diperoleh nilai kapabilitas proses multivariat $\left(M C_{p m}\right)$.

$$
\begin{aligned}
& M C_{p m}=\frac{\operatorname{vol}\left(R_{1}\right)}{|S|^{1 / 2}(\pi K)^{k / 2}[\Gamma(k / 2+1)]^{-1}} \times \frac{1}{\left[1+\frac{m}{m-1}\left(\overline{\boldsymbol{p}}_{\boldsymbol{j}}-\boldsymbol{T}_{\boldsymbol{j}}\right) \boldsymbol{S}^{-\mathbf{1}}\left(\overline{\boldsymbol{p}}_{\boldsymbol{j}}-\boldsymbol{T}_{\boldsymbol{j}}\right)^{\prime}\right]^{1 / 2}} \\
& M C_{p m}=\frac{\operatorname{vol}\left(R_{1}\right)}{\operatorname{vol}\left(R_{2}\right)}=\frac{0.0052}{0.00459}=1.1329
\end{aligned}
$$

Pada perhitungan kapabilitas proses multivariat $\left(M C_{p m}\right)$ menghasilkan nilai $1.1329>1$, sehingga proses multivariat dari variabel loom, preparation, dan spinning adalah capable.

\section{KESIMPULAN}

Kesimpulan yang diperoleh pada penelitian ini adalah perhitungan kapabilitas proses multivariat $\left(M C_{p m}\right)$ diagram kontrol multivariat $n p$ dari variabel loom, preparation, dan 
spinning dengan menggunakan data proporsi yang dibagi dengan jumlah keseluruhan sampel dan memperhatikan korelasi antar variabel, diperoleh nilai $M C_{p m}=0.625142<1$, jadi proses multivariat tidak capable dikarenakan banyaknya pengamatan yang berada di luar spesifikasi sehingga perlu dilakukan adanya perbaikan proses. Sedangkan perhitungan kapabilitas proses multivariat $\left(M C_{p m}\right)$ diagram kontrol jarak chi-square dengan menggunakan data proporsi yang dibagi dengan jumlah sampel pada tiap pengamatan, serta tidak memperhatikan korelasi antar variabel, diperoleh nilai $M C_{p m}=1.1329>1$, sehingga proses multivariat capable dan hampir semua pengamatan mendekati spesifikasi.

\section{DAFTAR PUSTAKA}

Daniel, W.W. 1989. Statistika Non Parametrik Terapan. Jakarta: PT Gramedia.

Johnson, R.A., dan Wichern, D.W. 2007. Applied Multivariate Statistical Analysis Sixth Edition. United States of America: Pearson Education.

Lu, X.S., Xie, M., Goh, T.N., dan Lai, C.D. 1998. Control Chart for Multivariate Attribute Processes. International Journal of Production Research, Vol:36, No.12, ISSN 34773489.

Montgomery, D.C. 2013. Statistical Quality Control, Seventh Edition. Singapore: John Wiley \& Sons.

Mukhopadhyay, A.R. 2008. Multivariate Attribute Control Chart Using Mahalanobis D2 Statistics. Journal of Applied Statistics, Vol.35, No.4, 421-429.

Ye, N., Borror, C.M., dan Parmar, D. 2005. Scalable Chi-Square Distance versus Conventional Statistical Distance for Process Monitoring with Uncorrelated Data Variables. Quality and Reliability Engineering, 19:505-515.

Yuswantana, B., dan Haryono. 2010. Pengontrolan Kualitas Produksi Mebel Jenis Kursi Indoor di PT MAJAWANA dengan Diagram Kontrol Multivariat Atribut Berdasarkan Jarak Chi-Square. Institut Tekonologi Sepuluh Nopember. Digilib.its.ac.id (diakses tanggal 15 Deseember 2017). 